\title{
From the "Millet System" to a Hostage Minority: Greek Community of Turkey or a Trump Card in Cyprus Issue 1954-1955
}

\author{
Resul Babaoglu
}

\begin{abstract}
The Cyprus issue, especially since 1951, was evaluated as an important topic in Turkey's foreign policy agenda. Since that date, Cyprus issue has created the main reason of the tension observed in the relations with Greece. On the other hand, this negative table also had too deep effects on the Greek originated citizens of Turkey. For the realization of the purpose of connecting the island of the Greeks to Greece, the offensive and destruction actions against the Turks and the British rule after a short time in Turkey found correspond to the nationalist reflexes. In this article, by investigating the effects of the tension lived in Cyprus to Turkey Greek community, the difficulties and societal responses caused by that period are evaluated in terms of Greek community. The negative impacts of the Cyprus problem on the Turkish Greeks have been evaluated by the newspapers articles and the memories which are conveyed to the current times.
\end{abstract}

Index Terms-Cyprus, Turkey greek community, greece, Turkey.

\section{INTRODUCTION}

The Ottoman Empire was a multinational empire consisting a variety of language, religion, nationalities, races and cultures. Since at the founding of the Ottoman Empire, the imperial minorities living within the borders of the Ottoman millet system are given the opportunity of keeping peace and order in the ethnic and religious identities. The most important element of non-Muslim subjects of the Ottoman Empire was the Christians that have been gathered around the Greek Orthodox Church [1].

Greeks undertook tasks such as translators in Divan-i Humayun. Greeks brought to these important positions created them to achieve great advantages of social life and strengthening Greek status by opening the way for the creation of a kind of Greek aristocracy in Istanbul. The Greek society, under the rule of the Ottoman Empire with a major economic advantage had a special status in the legal field as well [2].

Since $18^{\text {th }}$ century when the Ottoman Empire began to lose power in military and economic areas, the non-Muslim subjects who continue to live under the protection of European great powers have had better conditions than in the past through the reforms undertaken during this period [3].

From the $19^{\text {th }}$ century, non-Muslims united around the idea of nationalism strengthening self-identity increasingly due to

Manuscript received February 15, 2014; revised April 27, 2014.

Resul Babaoglu is with the Ankara University, Institute for Ataturk Principles and History of Turkish Revolution (e-mail: babaogluresul@hotmail.com). the weakening of the central authority. It can be said that non-Muslims in the Ottoman Empire lived the most comfortable period in every aspect especially as demographically from the declaration of the Kanun-u Esasi (The first Meshrutiyet period) in 1876 to the World War I [4]. On the other hand, the Young Turks' (Jeune Turq) appearing in political scene and working to place the secular order across the country has also influenced the Greek society. During this period, the Greeks sent the chosen people to Meclis-i Idare-i Vilayet and Karma Milli Meclis. [5]. When evaluated in this respect, the Ottoman Greek community has also finished the attribute of absolute leadership of the Patriarchate by creating its own bureaucratic elite through elections. Thus, the Greeks, for centuries, have begun to position themselves as a political force beyond being perceived as a religious community.

With the outbreak of the World War I, despite all the objections a great distrust of the Greek men in the army has emerged. The Greeks, who had the potential of collaboration with the enemy during the war, put forward their bad intentions with the communities primarily set up during the National Struggle. To re-establish the Byzantine Empire and realize the Megali Idea ${ }^{1}$, they established communities such as Etnik-i Eterya, Mavri Mira and Pontic Greek (Pontus Rum). Greek associations that do not stop to give any support to the Greek occupation of Western Anatolia attempted to perform their aspirations providing support of the British [6]. However, with some developments such as opening of Turkey Great National Assembly, National Struggle's being more organized and the establishment of Regular Army has reduced the threat of the Greek. By the end of the War of Independence, began a mass migration of Greek which directed all over Anatolia to Istanbul. According to statistics, the population of Greeks living in Istanbul reached 250000 in 1922 [7].

According to the Treaty of Lausanne signed after the acquisition of the War of Independence, all minorities remaining a Turkish citizen have been adopted by counting the Fener Greek Patriarchate in Istanbul. With this article, Greeks' in Turkey easily continuing their religious and cultural assets has been grown [8]. In addition, according to the additional protocol in the same treaty under the heading "Turkish-Greek compulsory exchange of populations" excluding the Greeks residing in Istanbul and the Turks of Western Thrace mutually alternated. As a result of the Treaty

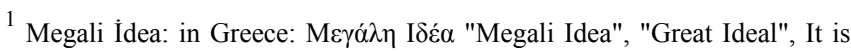
Greek Ideal which is active since the date Fatih Sultan Mehmet gave an end to the Byzantine Empire.
} 
of population exchange, the Greek population of Anatolia has had a considerable reduction in the extent. For this reason, exchange of populations, which was considered to be the beginning of the end of the Greek presence in Asia Minor, also has been in the ideological codes of the Greek political life as the bankruptcy of the Megali Idea for many years [9].

The Republic of Turkey established after the acquisition of the National Independence War started a new period of time in foreign policy with the modernization initiatives, as well. The Republic of Turkey which aims to establish good relations with neighboring states and establishing good relations with Greece are naturally led to favorable conditions for the Greeks living in Turkey. The Greek leaders' adopting a conciliatory attitude with the avoidance of repeating the mistakes of the past has been an important factor in achieving peace and entering the peace process and as a result. With the positive relations with Greece, which was established during this period, the Greeks living in Turkey have seen the reflections well. It was this time when the Minorities gave up their rights under the Article 42 of Treaty of Lausanne which is about the non-Muslim citizens living in Turkey can base on their own traditions and customs to solve problems with the law of families and people [10].

In the early years of the Republic, it was kept away from differentiating treatments to the non-Muslim Minorities in the process of structuring nation-state. Indeed, Article 88 of the 1924 Constitution concerning citizenship included "The inhabitants of Turkey without distinction of religion, and race shall be as Turkish citizenship". As understood from this article, the concept of Turkishness was based on the principle of citizenship rather than an ethnic definition.

In the 1930s, the Turkish government administrators' good intentions against minorities have become apparent. There was no government intervention in the selection of the Patriarch took place October 7th 1930. On November 1st 1930, Greek Prime Minister Venizelos Patriarch visited Fotios II. Thus, it was the first time that such a visit was allowed. On the other hand, On the occasion of correspondence in the 7th anniversary of the Republic of Turkey, it was seen that Mustafa Kemal cited Fotios as "Patriarch" in response to Fener instead of using the expression 'archpriest'.

On August 26, 1932 Prime Minister Ismet Inonu and Foreign Affairs Minister Tevfik Rustu Aras also participated in an event organized by the Greek community in Istanbul [11]. Non-Muslims are allowed to work in the People's houses with regulations issued by the RPP in 1937. Greek minority living in Turkey have benefited from these favorable conditions, and strengthened its presence in the community institution.

\section{TURKISH-GREEK RELATIONS IN THE PERIOD OF DEMOCRATIC PARTY}

Convergence and mutual good faith lie on the basis of relations with Greece developed positively during the Democratic Party in recent years. One concrete indicator of the mutual positive attitudes is seeking refuge in Turkey, the Greeks who fled the Nazi occupation from Greece in World War II.
After the end of World War II world-wide spread of freedom and the democratization process in Turkey gave birth to transition to multi-party life and this process has given rise to the air of freedom which includes non-Muslim minority in the country [12]. Single party rule was the primary obstacle to the institutionalization of democratic values especially represented by the western countries in Turkey. After World War II, Turkey's pro-Western stance against the Soviet threat has brought with a multi-party system [13].

Some internal factors for the introduction of a multiparty system made its presence felt in this period. An anxious front arose from one-party rule's social, political, and cultural practices, a wide range of difficulties due to various reasons in Turkey [14]. The Democratic Party that grew stronger in a very short time with the support of this exciting group has made success in the 1950 elections. It made the success that could not find in 1946 elections [15].

In these elections participation rate was greater than $80 \%$, while DP getting $53.5 \%$ of the voting in parliament by winning four hundred and eight of four hundred and eighty, RPP had only sixty-nine deputies. The Democratic Party, rising as the ruling party, had complete harmony between election promises and party program. Specifically emphasized economic understandings such as liberal economy, free market economy, encouraging foreign investment provided important clues about general politics of the Democratic Party in the power.

Non-Muslim minorities voted for the Democratic Party which offered a more moderate view than RPP. The leaders of religious minorities clearly supported the Democratic Party by showing different attitude from the traditional avoidant attitude in 1950 and 1954 elections. Indeed, during this period, rates of non-Muslim minority votes have increased.

The course of the relations established with Greece had direct impact on the lives of the Greek minority living in Turkey. In some issues such as good relations established with Greece in the early years of the power of the Democratic Party and cultural co-operation, Greeks living in Turkey was seen as a bridge. Via the Treaty of Culture signed by the Turkish-Greek on April 20 ${ }^{\text {th }} 1951$, the Greeks living in Turkey had the opportunity of development in the political, economic and cultural fields.

The establishment of the Turkish-Greek Friendship Association on May 5th 1952, and the negotiations concluded with an alliance agreement. Thanks to the Turkish-Greek Cultural Agreement signed on April 20th 1951, the Greeks living in Turkey had the opportunity of progress in the political, economic and cultural fields. Both countries have made efforts to sustain the positive developments in the Turkish-Greek relations in the early 1950s. In January of 1950, the Minister of Foreign Affairs of Greece Tsaldaris, in a speech to the Turks living in Western Thrace, expressed by emphasizing the importance of good relations that Turkish-Greek relations can be achieved not only at the official level but through the joint efforts of the peoples of the two countries. Tsaldaris also expressed his belief on these efforts would bring the two countries into a dynamic two partners of the world [16]. As can be seen, in 
these years, ruling circles of the two countries reflected the positive atmosphere created by these relationships to the citizens of minorities in line with the relations established in the course of this is the official level.

Political and military polarizations occurred after World War II has affected Turkey's foreign relations greatly. Turkey and Greece had an important role in the United States' new security system against the Soviet and Bulgarian threat during the Cold War in the Middle East [17]. To ensure the security of the Mediterranean Sea and reduce the domain of Soviet Russia in the Middle East, Turkey and Greece had to be included in a new security system. On the other hand, Western countries, heading the U.S., were unhappy about the increase of Soviet political influence in the southeast border in the Middle East, the Soviet military presence in Turkey's northwest and northeast borders [18].

Turkey and Greece's being under security via joining NATO, positive impact on all aspects of bilateral relations arose. This rapprochement would strengthen further via mutual official visits. At this dates, following the President Celal Bayar's visit in Greece, the Greek king and queen visited Turkey [19].

With the mutual visits and signed agreements in the early years of the Democratic party Turkish-Greek relations were strengthened. These developments led to flourish the hopes for the future periods for the peoples of the two countries and in particular for the Turks of Western Thrace and Greeks in Turkey.

\section{REFLECTIONS OF THE GREEK-TURKISH RELATIONS ON THE GREEKS OF TURKEY}

Rapprochement between Greece and Turkey had a positive impact on the populations of, in particular, the Turkish and the Greek minority in the country. Both governments thought that making significant improvements in life conditions of minority communities is important in softening relations of both governments and convincing mutual public opinion. These positive relations also affected the Turks in Western Thrace. Greek officials' recognizing the Turkish educational institutions and not creating an obstacle in religious beliefs have been outcomes of the positive political relations.

This positive outlook on foreign policy reflected positively in the same way on the Greek community living in Turkey. The number of primary schools which forms the basis of the school system increased from 44 to 51 during this period, the Orthodox clergymen are allowed enter the schools again.

Of other non-Muslim communities living in Turkey, the Greeks had a separate position. Negative feelings deep inside against them were formed in the wider community because of their cooperation with the occupying forces during the War of Independence. However, after the transition to multi-party system, along with the liberal understanding affecting the country's political and social life, a more moderate approach emerged against the Greeks.

In 1951, along with the culture agreement with Greece, two countries, mutually ending hatred accusations in school textbooks, launched an era in which good relations would be installed [20]. The Turks living in Western Thrace were also influenced with the benefits of the new era. In fact, for the first time in 1951, for Turkish originated who is accepted as the Muslim minority in Greece, the expression of the Turkish minority was used. During this period, significant improvements have been made for the minorities. Service records which are lost due to fire and occupations were given to the minority teachers and managers of schools in June 1950. On the other hand, the Prime Minister Adnan Menderes being the first Prime Minister of the Republic of Turkey to visit the Fener Greek Patriarchate this period together with the Minister of Foreign Affairs is important to reflect the DP's perspective of minorities in government [21].

On May 27 1955, with the Law related to Turkish and culture teachers of minority schools, an improvement of salary was made for teachers in charge of the minority schools and they have achieved the same personal rights with colleagues working in the Turkish schools. In addition, mutual aid on the basis of the benefit from educational materials and tools in the Greek schools was decided to be done with the Turkish schools. The Halki seminary was converted into college by improving the status during the DP period. Langa Private Greek minority primary school was opened in 1952 with courtesy of the Democratic Party [22].

During the Democratic Party period, Greek citizens have existed in the press. They assessed socio-cultural and political events freely developing communication in the community in such newspapers as Apoyewmatini, Embros, Tahidromos [23].

\section{THE CYPRUS ISSUE AND ITS EFFECTS ON THE GREEK-TURKISH RELATIONS}

\section{A. Historical Background}

As Island of Cyprus is found in a strategic position that makes it possible to control a wide area of Asia Minor, Syria, Egypt and the Middle East, it has been part of the land that states want to add their own territory wishing to prevail in this region throughout the history.

Along with Cyprus' passing from the Venetians to the Ottoman Empire's sovereignty in 1571, a strong Turkish authority on the island was settled in the island with Turkish population. The security of Mediterranean trade has been largely provided in this way. With the end of the colonial order established by the Venetians on the island by this way, Ottoman rule was welcomed by the people of the island. After the domination of the Ottoman, there has not been any problem between the Muslim Turkish settlers in Cyprus and the native people of the Greek Orthodox population until the Treaty of Berlin 1878.

As a result of great powers' performing some calculations on the island of Cyprus, some important developments were paving the way for deeply affecting the management of the Island and the structure of society.

When the states especially Britain started to pay attention in seeking to dominate in the Middle East of the island of Cyprus, it was equivalent to years of occupation of Egypt in 1882. After the end of the Ottoman-Russian war with the Treaty of Berlin, the UK has acquired the right to keep troops 
on the island in exchange for his political aids to the Ottoman Empire [24].

The United Kingdom, firstly after settling the island, in order to reduce the dominance of the Turkish in the island, sent Turkish descent officers away and assigned the Greeks to higher positions. These had severe effects on the Turks economically. Turks were forced to move on their lives by selling the land and property in their possession. The Greeks benefited from this opportunity, provided a strong asset in Cyprus by buying the property the Turks. The Turkish population who has difficulty adjusting to this bad situation, after a short time, decided to immigrate to Anatolia [25]. However, the Greeks have turned in their favor of the demographic structure of Cyprus by supplementing the island population. The Greeks who had the majority of the population in the island and strengthened in the administrative and economic field, they have made various activities for annexation of the island to Greece in the next term [26].

The British, as well as all the other colonies, skillfully exploited Cyprus in every field. What they get has always been much more than what they give. The layout that built by the Ottoman Empire on the island, and based on the nation system left its state to uncertainty after the domination of the British. Shortly after the start of the First World War, the British that holds management of the island, according to some sources, suggested Cyprus to Greece as a reward in case of joining Greece into the war against Germany. However, the king of Greece, who was not capable of predicting the foreign policy in that period, did not accept such an offer [27].

Britain's domination of the island of Cyprus continued in later years, and finally 16, 20 and 21th articles of the Lausanne Conference was recognized and formalized by Turkey. According to the article 21 of the Treaty, Cyprus citizens of Turkish origin had to choose one nationality of England or Turkey within two years. Migration of Turkish origin who chose Turkish nationality in the island led the Greeks to have a voice in the social and economic aspects on the island in the coming years. In addition, the suppression of the Turkish population got easier [28].

On the other hand, the Greek Cypriots were not idle. In 1929, the Greek Cypriot representatives forwarded some of the requests to London. As this did not occur, the Greek Cypriots revolted in the autumn of 1931.

The revolt that began in Limassol broke out in other provinces of the island in a short time. Crowds supporting the rebellion which was led by the priest Dionyslos Kyklotis walked toward the governor's mansion and they burned province mansion ignoring the warnings of the police force. When it is understood that the British administration wouldn't take enough precautions, military reinforcements to the island were done again [29].

Disturbances that began in 1931 in Cyprus increased with the Cyprus Orthodox Church's spreading the idea of union with Greece and it's constantly accumulating fans.

\section{B. The Emergence of the Cyprus Issue and Enosis Ideal of Greece}

After the World War II, Greece recovered with the assistance of American and Megali Idea (Great Ulku) in which the demand of the target of the unification of Cyprus with Greece, the homeland, (Enosis) began to appear by the year 1950. However, during and after World War II, the Cyprus problem often raised and provoked in Greece. Greek Prime Minister, Metaxas, reported that Cyprus would be given to Greece at the end of the war while the war was continuing [30].

The prevalence of colonial movements after the Second World War turned Greece to integration policy with Cyprus by putting an end to the dominance of the British. For this purpose, the Greek Cypriots began to perform bloody deterrence methods (terrorism) including demonstrations and actions to integrate the island with Greece.

In 1945, more moderate policies were carried out on colonialism with the coming to power of the Labour Party in the UK (The British Labour Parthy). The Labour Party came to the fore with the political attitude towards anti-colonialism besides social policies. In accordance with these policies of the Labour Party, the British army abandoned India in 1947 and Palestine in 1948. With the emergence of this favorable political conditions, the claims that the Greek Cypriots joining to Greece and Greece's annexation of the island of Cyprus has begun to strengthen. This period's global conjunctural structure created by the principle of self-determination led by the United States and the United Nations, the colonial order's criticism after World War II meant that Greece was moving with right schedule.

In 1947, the representatives of the Greek communist party of right-wing did an interview with the Minister of Colonies taking into account the current political situation in the UK in London. Cyprus joining with Greece was discussed at the meeting held. The UK was opposed to this request as did the Turks in the island. However, the Greeks continued these visits continued with increasing frequency. On Sunday, January 15 1950, the Orthodox Church of Cyprus organized an informal plebiscite (Public rating) for union with Greece. After a while, the Church announced that 215000 Greeks out of 224700 voted in favor of "participation" [31]. British and Turkish governments certainly rejected the results and the voting that was just attended by the Greek Cypriots. 800 Turk Cypriots voted in favor of union with Greece [32].

Shortly after the referendum of 1950, Archbishop, Makarios II, died. III. Makarios the Metropolitan bishop of Kiti was elected as a new archbishop on August 20, 1950. Young archbishop was still 37 years old when he took office. The young archbishop who was trained in Athens and Boston universities was ambitious and willing [33]. The archbishop, in a speech at the public ceremony coming in authority of the archdiocese, vowed that he will do everything in its power for the island's union with Greece. More importantly, Makarios, in his speech said: "Under this holy dome, let's vow the saints in faith. We will not compromise on! We will not compromise on! No Compromise! Will prevent bullying and violence. With our increased courage, we will exhibit our honorable stance against thorns that have an eye on us, and only the annexation of the annexation" [34].

Cyprus Archbishop Makarios, in 1951, invited the the Greek officer Grivas to Cyprus and gave him the task of organizing the Greek Youth Organization, PEON. After 
PEON was closed due to malicious activities and provocative stance by the British Government it re-taking the name of EOKA continued to operate in the service of Makarios. The EOKA which is equipped with modern equipment to set up an underground hospital and organized all over the island of Cyprus, were performed extortion and attacks not only against the Turks and the British but also against the Greek Cypriots who did not accept his own principles.

"Progressive Party of Working People" (A.K.E.L.), established by the communists in Cyprus, began to carry out the case of Enosis working cooperatively with the Orthodox Church on the island. The Soviet Union during the Cold War used the communist structure in Cyprus in order to ensure the field of operations in the Mediterranean. Greece beginning to utter the annexation policy on the Cyprus at the expense of the displeasure with the UK, one of the Western allies, is a political attitude largely as a result of the efforts of the communist AKEL Party performing political activities on the island [35].

Communist A.K.E.L. Party formed the center of the nationalist movement on the island. This party intended to implement the aim of being the single judge of the struggle launched himself by using all kinds of methods including radio propaganda and signature campaigns against the British rule [36].

Greece, since 1951, has been in an active policy in the international arena moving up the Cyprus issue. The issue, firstly, by being brought to the Greek parliament was said that Cyprus joining with should be carried out. In November, the same year, negotiations would start with the United Kingdom, the actual owner of the island. The Greeks promised Britain with a base on the island in exchange for the abandonment of the island for themselves, but this request was rejected. Thus, this political maneuver which can be considered the first of the efforts of joining the island to Greece ended in failure. Greece, after this stage, tried to announce the ideal ENOSIS to the public in the whole world undertaking terrorist activities in order to annex Greece.

Greece and the Greek Cypriots saw the Turks as an obstacle to the realization of Enosis. Therefore, the Greek Cypriots began bloody terrorist acts to neutralize the Turks on the island and joining Cyprus to Greece. When the EOKA organization, which was founded to carry out such actions, raised the bloody attacks of the Turks, some of the Turks on the island formed an anti-terrorist group called "Volkan". However, this founded organization remained quite passive against the EOKA [37]. Some of the Turkish on the island, under the leadership of Dr. Fazil Kucuk, established "the Turkish Cypriot National Unity Party". Fazil Kucuk claimed the island to be left to Turkey in case of the withdrawal of Britain. Therefore, when the slogan "Cyprus is Turkish" comes to become common, he changed the name of the party as "Cyprus is Turkish Party".

When opposition parties in Greece declared the annexation of Cyprus as "the national case" on July 30 1954, authorities of Greece started political initiatives internationally by deciding to take the Cyprus issue to the United Nations to realize his ideal of ENOSIS.

Between 1954 and 1958 the Greek authorities appealed to the United Nations for Cyprus five times [38].
Internationalized the issue with Greece carrying the subject to the United Nations, and thus the 60 members of the United Nations were informed on the subject.

In an application to the United Nations on August 20, 1954, the Greek authorities demanded the implementation of Self-Determination on the island instead of demanding the island to be given themselves overtly.

Political Commission of the United Nations reported that the Greek Thesis cannot be considered by explaining that decision-making about the issue wouldn't be appropriate on December 15, 1954 [39]. The rejection of Greek's demand on Cyprus people self-rule by the UN Political Committee disappointed the Greek-Cypriot side. Upon this decision, the masses of students protested in the streets in Greece. A group of demonstrators in Athens threw stones at the British and American embassies. Following the negative decision of the $\mathrm{UN}$, the nationalist circles protest in Greece also protested in front of the Embassy of Turkey [40].

Regarding the United Nations decision on Cyprus, Prime Minister Adnan Menderes expressed satisfaction on the decision made in a language which is quite cool to the Anatolian Agency in a statement.

However, an undesired solution to the Cyprus issue not arising by the United Nations political committee is a situation that satisfies Greece. Greece, which aims the creation of self-determination management on the first stage on Cyprus and joining the island to homeland, has increased its support to the EOKA organization after unsuccessful diplomatic attacks undertaken. During this period, in the leaflets distributed in Cyprus, it was reported that ideal of union with Greece was declared all over the world and those who do not serve for this purpose would also considered to be a traitor [41]. When Greece did not get a result of political initiatives, Greece tried to settle for a solution in line with their own purpose in Western countries increasing the violence on the island and attracting the attention of the international community.

\section{Turkey's Involvement in the Cyprus Problem}

During the cold war, the positive political relations between Turkey and Greece are largely the result of positioning themselves next to the western countries in the present table. As the important actors of the security system of NATO in this period, the Turkish and Greek policy-makers, sought to develop political and cultural relations between the two countries. However, since 1951 Enosis policy followed by Greece in Cyprus did not take Turkey's response initially, but along with this, Turkey got involved in the Cyprus issue with official discourses especially as a result of press and civil society organizations' effective propaganda activities.

Essentially, the silence break of Turkey on Cyprus is not because of the Turkish Cypriots under the threat of violence but also it is closely related to fear of endangering the southern coast in in the event of a possible change in management in Cyprus [42]. However, in the face of the Greek's Enosis attempts, Turkey's remaining silent could not be expected. Mistake made on the Dodecanese Islands in 1947 are not required to be repeated [43].

Upon Greek Prime Minister Sophocles Venizelos' taking 
forward formally annexation of Cyprus to Greece on February 16, 1951 [44], the first reaction in Turkey was from the press the journal of Zafer which is close to the government. In the review news, it is emphasized that Venizelos' statement should be evaluated as a new stage of the Cyprus problem, even the statesman who has secondary responsibility take the case of Cyprus and the Greek government believe the secret works to bring consistency.

On behalf of the Government, the reaction to the statement made by Prime Minister Venizelos 'began with a statement of Minister of Foreign Affairs Koprulu in the Hurriyet newspaper on the April 20th 1951 [45].

Democratic Party government was caught unprepared in the face of Greece taking Cyprus to the United Nations. Furthermore, while it was avoiding a disproportionate respond on behalf of the friendship established with Greece, it could not conceal the concerns about the island of Cyprus. Foreign Minister Fuat Koprulu stated his counterpart Yoannis Politis that if Cyprus problem arose, this situation would be the end of the Turkish-Greek friendship.

While large demonstrations were in favor of Cyprus and Enosis in 1952, in the meantime, when Greece could not make the UK accept Enosis diplomatically, it chose to pull the problem to the international arena in accordance with the traditional policy. Greek delegate, Dimitrios Lampros in a speech made at the United Nations session on November 24 1952 requested the implementation of the right of Self-Determination in Cyprus. Adil Derinsu who responded this said that not only the Greek Cypriots, but also the Turks lived in Cyprus and the same right should be given to them.

However, during this period, despite the DP Government indicate the sensitivity of the Cyprus issue with official statements, did not request initiatives that would arise tension. When it is evaluated in this regard, it can be better understood that the required demonstrations have been banned in Izmir on September 91953 and September 91954.

Since 1954 when the acts of EOKA have reached catastrophic proportions in Cyprus, in parallel with this, the national excitement that affects the general public also seems to have increased. On the other hand, the community of Cyprus is Turkish and the federation of Turkey National Students which were established concerning Cyprus, has invited to take an efficient and stable stand on this issue via the meetings and actions organized.* In addition, there have been economic consequences on Cyprus sensitivity. The bank of Yapı Kredi abandoned opening a branch in Cyprus due to the events in 1954 [46].

The dismay caused by EOKA terrorist activities continuing with Greece's support in a large extent on the island started processing intensively in the Turkish press, especially during April and May of 1955 and this point has led to widespread negative attitudes towards the Greeks living in Turkey in also social sense by promoting the government in active policy-making.

In Lefke on June 21 1955, in an attack to the Turkish quarters carried out by the Cypriot activists, 14 Turkish were injured. In a statement issued by the Turkish National Students Federation, it is indicated that 24 million Turks in homeland are as always with his brothers in the Greek, their hearts hit for them and the participation of Cyprus comes true sooner or later. More than 500 people who applied TNSF and the community of Cyprus is Turkish in Istanbul on June 24 1955 requested to go to Cyprus and respond to the Greeks over there. On the same date, TNSF dispatched a telegram to Fazil Kucuk, the Secretary General of the Cyprus National Turkish Union, and Cyprus Turkish High School Union. On the other hand, on behalf of the Turkish Cypriots, the Turkish Union also sent off a commitment telegram to the Prime Minister Adnan Menderes [47].

Due to the fact that the Cyprus issue engaged in Turkey's domestic political atmosphere intensively, the Adnan Menderes, via making a change in cabinet [48]. Ordered Fatin Rustu Zorlu, appointed as the Minister of Foreign Affairs, to begin working without delay on Cyprus by setting up a commission. Thus, the Turkish government's official stance on the Cyprus was determined, as well as some strategies have been developed.

In August of 1955, mutual explanations that tense the atmosphere on Turkey and Greece press have been made. According to a report in the daily news, Milliyet, how the Greek official authorities look at the terrorist activities in Cyprus is revealed in Athens Radio.

Provocative news on the Greek media also quite worried the Turkish side [49]. The rumor of an attempt of massacre against the Turks on the island on August 28 spread quickly [50]. The rumor of massacre led Turkey give Note to the UK. In the Note, the expressions that Turkey can remain no longer silent if the terrorist actions initiated against the Turks in Cyprus received a measure took place.

Britain's providing dominance in Cyprus had a great importance to control the Suez Canal. So England has shown many attempts to end the climate of violence in Cyprus. When England could not get a result from the meetings with, especially, the USA Greece and the Greek Cypriots, she decided to organize a conference in London on 29 August 1955. Cyprus was the subject which was to be discussed at the London Conference titled as "Security Issues in the Eastern Mediterranean". The real reason for Britain's resort to such a way was seeing Cyprus as a matter of its own internal issue. The Anthony Eden government's decision to organize the conference and then inviting Turkey on June 30 1955 has led to opposition by the Greek Cypriots. Great Britain aimed to hinder Greece taking Cyprus issue to the UN by organizing this conference. However, the United Kingdom was aware that she didn't have much time left on the island in terms of management and thus she was planning to provide various benefits on the island for the coming years.

Turkey has started to make the necessary preparations by welcoming the invitation of the UK to join the conference with pleasure. At the London Conference which can be considered one of the breaking points, England tried to gain time to diminish the strength of Greece by including Turkey to the issue.

Days before the start of the London Conference, the Prime Minister Adnan Menderes set out the degree of hardness in the new policy that Turkish side developed in the Cyprus issue in the speech. It was recorded as August 24 Speech in the Liman Restaurant in the presence of some members of the government and the press.*

Before the Turkish delegation leaving to the London 
Conference to participate in this conversation, positive reactions of people in all walks of life were seen across the country. Opposition parties have repeatedly declared that they are next to the government in the statements on the Cyprus issue. RPP leader Ismet Inonu, in a statement cited in Ulus Newspaper which is close to the party conveyed the message clearly that "We are together with the government" [51]. Until the result of the conference was certain and pay attention to this issue as the opposition.

The leader of C.M.P. Osman Bolukbası has expressed great satisfaction because of the remarks that the prime minister had made on the violence in Cyprus [52]. It is evident that the August 24 Speech which have received the approval of the opposition, press organizations, intellectual backgrounds and almost all segments of civil society organizations revealed that Turkey was more sensitive and uncompromising than in the past.

\section{REFLECTIONS OF THE CYPRUS ISSUE ON TURKISH CYPRIOTS}

Days before the London Conference, the strongly worded statements of Prime Minister Menderes were very important in order to establish a general public on the Cyprus issue. On the days when The Turkish delegation was prepared to go to London, the Turkish press gave quite more importance to the Cyprus issue. When looked at the reports in this respect, it was seen that citizens of Greek origin living in Turkey and the Phanar Greek Patriarchate were involved in the incident.

In parallel with the development of Turkish-Greek relations, when evaluated on the fact that Turkish Cypriot citizens follow fluctuating relations which was established by the state and society, Greek originated Turkish citizens, in this period, had some very difficult times via the emergence of the Cyprus issue. After all, the campaign Cyprus is Turkish which was launched under the leadership of Turkish media eventually returned to the opposition of Greek.

The press and certain circles in Turkey have shown a strong response to the escalation of violence initiated by EOKA against the Turks on the island of Cyprus. In order to support the activities of EOKA, on the ground that Greek citizens living in Turkey and the Phanar Greek Patriarchate collected money and sent it to Cyprus, defamatory campaign, launched by especially Hurriyet newspaper against the Patriarch Athenagoras, made the public show general reaction against minorities. Some of the criticism made for Patriarchate is related to why EOKA was not criticized and Makarios was not interfered. Religious Affairs Chairman Eyup Sabri Hayirlioglu stated that it was makrooh, abominable and deserving punishment as Patriarch Athenagoras remained silent to the terrorist events in Cyprus.

Another issue that Patriarch Athenagoras was criticized is why he did not condemn Cyprus Archbishop Makarios. The articles in the Turkish press constantly criticize the Patriarchate as they are just an onlooker to the violence on Cyprus. In also Yeni Sabah newspaper, particularly in Hurriyet, the Patriarchate's remaining silent on Cyprus was stressed with harsh words. In a report in the Yeni Sabah, it is stated that the patriarchate's remaining silent in the face of violence means that the events are approved by directly targeting [53].

In these days of debates in press reports it was stated that the Greek foundations and the Halki Seminary provided financial support to the organization of EOKA. This kind of news in the papers thoroughly strained the environment. As a result of adverse environment, Patriarch had undergone even physical assault by some people in Eminonu.

When looked at the newspapers of those days, the reactions to the actions towards the Turkish Cypriot can be seen reflected in the way news notification. In a report in the Hurriyet newspaper, it is stated that "While a Greek pilot was coming in Yesilkoy Airport, he did not officially run up the Turkish flag" In the same newspaper, it is notified that "the Greek gangs in Cyprus continue the terrorist activities" Another news in the papers was concerned with the Patriarchate: "Denunciations were made on the way that Patriarch Athenagoras supported Turkish opposition on Cyprus." [54]. In addition to this report, largely based on rumors among the population in the same newspaper published by the Turkish National Student Union was ended with a sarcastic statement "...ecumenical Patriarch Athenogoras Sir His Holiness!”(... okumenik Patrik Athenogoras Efendi Hazretleri!)

Before the conference, CIT also, by speeding up its activities, prepared the community for the Cyprus issue to be sensitive. Particularly Hikmet Bil [55], president of the community, the Secretary-General Kamil Onal and Husamettin Canozturk and hundreds of members of the community handed out and hung posters written on "Cyprus is Turkish" to the public and disseminated the rumor that Turkish cemetery on Cyprus was attacked.

Hikmet Bil, who gave press release along with a group of Turkish Cypriots in Istanbul, responded to a question concerning August 28 being declared as the day of the massacre in an interesting way: "A very short answer should be given to this action! Istanbul has a lot of Greek." This statement which was the precursor that would occur in the following days reveals the temperature of the agenda.

Greeks living in Istanbul felt a great concern from this unfriendly attitude displayed by some groups. Along with the approach of the London Conference, an increase was observed in actions against Greeks. Feeling of insecurity felt by the Greeks in the face of these events reached serious proportions.

In different parts of Istanbul, the members of the community Cyprus is Turkish carried out several individual attacks by hanging posters to various places. Some of the actions of the Greek citizens' involvement and also those convicted are being Greek were brought forefront especially in the second pages of the newspapers. Particularly, on the days when the London Conference approached, the police had security measures around the Patriarchate and in the neighborhoods where Greek intensively live [56]. In every district of Istanbul just as Beyoglu or Buyukada, fights occurred between the Turkish and Greek youths.

August 30 Victory Day celebrations of 1955 were celebrated different from ever with the exceptional levels of national feelings. The news about the celebration reflected in the newspapers revealed the justification of the police in taking security measures. In an article titled "Disrespect was 
shown to the Fest" on the front page of the daily Hurriyet on August 31, it was expressed that Hilton Hotel and the Phanar Patriarchate remained in the dark at night time by not turning their lights on and this caused suspicion that Victory Fest was protested by them.

The negative news in the newspapers about the Patriarchate and the Greek living in Turkey led to tense air in İstanbul. As a result of this tense environment fights occurred between Turks and Greeks from time to time. On August 22, the member of the Cyprus is Turkish community's Mecidiyekoy branch hang posters of the community to the shops in Beyoglu. In the meantime, Cenyo Mordo, from the Greek nationality, working in a jewelry store did not want to hang out the poster and a discussion was occurred. Mordo, arrested by the police, an investigation began.

In a report in the Ulus newspaper based on a British author; it is suggested that 100 thousand Turks on Cyprus cannot accept the Greek administration and the primary concern of Turkey is Greece indicating that the second concern in terms of importance is the defense of Greece. [57].

Moreover, in these days, another rumor spread was that 600 Turks living in Western Thrace were collected in a mosque and burned. Such claims which came up by whom and on what resources based are uncertain, further increased the Greek hostility that already exists in the publicity and created the environment of the worst affairs which to be lived on $6 / 7$ September.

The national excitement during this period was greatly concerned with the issue of Cyprus. In fact, in those days, the size of the acts of violence geared towards the Turks in Cyprus has been a very high level. Because of the murder cases as a result of the terrorist attacks of EOKA, the general society approached with negative emotions to the Greeks in Turkey.

\section{CONCLUSION}

After the proclamation of the Turkish Republic, in accordance with the principle followed in the field of foreign policy "Peace at home peace in the world", positive relationships were established with Greece based on mutual good intentions. Thanks to both countries' administrators refraining from repeating the mistakes of the past, this positive picture emerged in Turkey has grown and developed since the start of multi-party political life.

There is no doubt that the most sensitive area affected by the Turkish-Greek states relations is the minority population of the two countries. Turkish citizens of Greek origin and Western Thrace Turks have experienced ups and downs in the historical process. The minorities that are highly affected from the interstate crises are almost viewed as a political object.

The membership of NATO that began with Democratic Party power in Turkey, accordingly, the pro-Western political attitudes brought strategic association along with Greece for many years. However, in 1951, the emergence of the Cyprus issue has led Turkey live problem with her ally Greece by shaking Turkey's overall political position. Mutual political moves made dragged the two countries in a crisis. The most obvious result of this negative situation is turning the rapidly rising nationalist wave in Turkey into a Greek opposition that cannot be hindered.

The violence and intimidation acts of EOKA, which had Greece's weapons and money support in Cyprus, started to reach unacceptable proportions against the Turks on the island and this had response in Turkey. Particularly, the community of Cyprus is Turkish and the Cyprus campaigns launched by leading media are well respected by the public. In addition to the organized awareness-raising meetings and signature campaigns, press releases and declarations having posts in which managers should execute a more active policy on this issue caused the government to make strongly worded official statements to the Cyprus problem.

By the year 1955, depending on the Cyprus issue, Turkey's political and social climate completely strained. This negative table turned into Greece and the Greek opposition around people. In this context, the Greek citizens of Turkey are perceived as extensions of Greece and negative attitudes were developed towards them. The newspaper reports of the period clearly show that Greek citizens of Turkey are evaluated as a party to the Cyprus problem in the public opinion and have been subjected to degrading treatment in this respect.

\section{REFERENCES}

[1] G. Augostinos, Asia Minor Greeks, Ankara: Ayrac Yayınları, 1997.

[2] G. Bozkurt, Gayrimuslim Osmanlı Vatandaslarının Hukuki Durumu (1839-1914), Ankara: Turk Tarih Kurumu, 1989.

[3] İ. P. Haydaroglu, Osmanl Imparatorlugu'nda Yabancl Okullar, Ankara: Kultur Bakanlıgı Yayınları, 1990.

[4] S. Akgonul, Turkiye Rumlarl, Ulus Devlet Cagından Kuresellesme Cagına Bir Azınlıgın Yok Olus Sureci, Istanbul: İletisim Yayınları, 2007.

[5] V. Kechriotis, "The modernisation of the empire and the community priviliges: greek orthodox responses to the young turk policies," The State and the Subaltern, New York, The International Institute of Social History, 2007, p. 112.

[6] İ. Oztoprak, Kurtulus Savast ile Ilgili Yunan Belgeleri, Ankara: Turk İnkılap Tarihi Enstitusu Yayınları No: 228, 2006.

[7] A. Alexandris, The Greek Minority of Istanbul and Greek-Turkish Relations:1918-1974, Athens: Center for Asia Minr Studies, 1992.

[8] S. L. Meray, Lozan Barls Konferansı Tutanaklar-Belgeler, İstanbul: Yapı Kredi Yayınları, 2002.

[9] A. S. Alpan, "But the memory remains: history, memory and the 1923 greko-turkish population exchance," The Historical Review/La Revue Historicue, cilt IX, pp. 199-232, 2012.

[10] A. Galanti, Turkler ve Yahudiler, İstanbul: Gozlem Gazetecilik Basım ve Yayın, 1995.

[11] C. Okutan, Tek Parti Doneminde Azınlık Politikaları, İstanbul: Bilgi Yayınevi, 2004.

[12] B. Lewis, Modern Turkiye'nin Dogusu, Ankara: Arkadas Yayınevi, 2009.

[13] O. Sander, Siyasi Tarih (1918-1999), Ankara: İmge Yayınevi, 2001.

[14] B. Tanor, Osmanll-Turk Anayasal Gelismeleri, İstanbul: Yapı Kredi Yayınlar1, 2004.

[15] T. Timur, Turkiye'de Cok Partili Hayata Gecis, Ankara: İmge Yayınevi, 2003.

[16] E. Taschounidou, "The case of greek orthodox minority pres of istanbul and the grek-turkish relations 1950-1955," İstanbul: Bilgi Universitesi, Sosyal Bilimler Enstitusu, 2009.

[17] Y. Sarınay, Turkiye'nin Batı Ittifakına Yonelisi Ve NATO'ya Girisi, Ankara: Kultur Bakanlıg1 Yayınla1, 1988.

[18] W. Hale, Turk Dis Politikası (1774-2000), İstanbul: Mozaik Yayınları, 2003.

[19] R. Babaoglu, 6/7 Eylul 1955 Olaylartnın Turkiye Rum Cemaati Uzerindeki Etkileri (1955-1959), Dicle Universitesi, M.S. Thesis, Sosyal Bilimler Enstitusu, Diyarbakır, 2012

[20] D. Madanoglu, The Position of Minorities in Turkish Foreign Policy (1923 - 1974), Bilgi Universitesi, İstanbul, 2007. 
[21] The Period of the Democtaric Party Should be Read in Reverse for Minorities, Yeni Safak, September 2011.

[22] N. Akman, "Adnan Menderes Who Judged for Assimilation Crime, Had Given Rights to the Minorities," Zaman, June 2011.

[23] E. Ozsuer, Turkiye'de Cok Partili Hayata Gecis Surecinde Rum Cemaati ve Apoyevmatini Gazetesi, Ankara: Yuklem Yayınları, 2012.

[24] A. Kuloglu and A. Ozkan, "Avrupa Birligi'ne Uyelik Surecinde Turkiye'nin Kıbris Politikas1,” Stratejik Analiz, cilt 4, no. 39, pp. 22-53, 2003.

[25] H. Oksuz, "Turkish Cypriot Migration to the Mainland," Tarih ve Toplum, no. 187, pp. 33-39, 1999.

[26] S. Sakin and S. Dokuyan, Klbrls ve 6/7 Eylul Olaylarl, İstanbul: IQ Yayınlar1, 2010.

[27] C. M. Woodhouse, Modern Greece: A Short History, London, 1998.

[28] C. Sar, British Policy Towards Cyprus and the Cyprus Question (1878-205), Ankara: Bilkent Universitesi, 2005.

[29] H. Bil, Klbrls Dosyasl ve İcyuzu, İstanbul: İtimat Kitabevi, 1976.

[30] N. A. Banoglu, Klbrıs Dosyası, İstanbul: Kervan Yayıncılık, 1974

[31] M. K. Oke and E. Mutercimler, Yalnızlıktan Saygınlıga Democrat Party'nin Dis Politikası, Ankara: Demokratlar Kulubu Yayınları, 2000.

[32] M. Mihailidis, "Kıbris turk isci sinifi ve kibris isci hareketi," Kıbrls Dun ve Bugun, M. Kurkcugil, İstanbul, İthaki Yayınları, 2003.

[33] A. Mango, "Eoka, enosis and the future of cyprus," University of Nicosia, Cyprus Center for European and International Affairs, pp. 3-6, 2009.

[34] Psirukis, Istoria Tis Singhronis Elladas 1940-1967.

[35] Z. Karaca, Fahri Coker Arsivi, 6/7 Eylul Olaylar Fotograflar-Belgeler, İstanbul: Tarih Vakfı Yurt Yayınları, 2005.

[36] Documents: Cyprus 1950-1954, The Prelude to the Crisis, Part 1. (1950). [Online]. Available: http://triceratops.brynmawr.edu/dspace/bitstream/handle/10066/5506/ Kitroeff_15_1-2.pdf?sequence $=1$

[37] F. C. Erhan, The Incidents of September 6/7 1955, İstanbul: Bogazici Universitesi, 1996.

[38] S. G. Xydis, "The UN General Assembly As An Instrument Of Grek Policy: Cyprus, 1954-1958," The Journal of Conflict Resolution, cilt 12, no. 2, pp. 2-29, 1968.

[39] General Assembly Offical Records Ninth Session, 514th Plenary Meeting, Resolution no: A/RES/814(IX). (December 1954). [Online] Available: http://www.un.org/depts/dhl/resguide/r9.htm

[40] Demonstration in fronf of the Turkish Embassy, Milliyet, December 1954.

[41] Turkish Cypriot Human Rights Committee, A Chronology of The Cyprus Problem (1878-1980).

[42] B. W. Beeley, "The Greek-Turkish Boundary: Conflict at the Interface," Transactions of the institute of British Geographers New Series, cilt 3, no. 3, pp. 351-366, 1978.
[43] E. Manisalı, Dunden Bugune Klbrıs, İstanbul: Yeni Gun Yayıncılık, 2000.

[44] Greek PM Sofokles Venizelos States that Cyprus Should Have Join to Greece, Hurriyet, February 1951.

[45] Turkish Minister of Foreign Affairs F. Koprulu, Shows a Strong Response, Hurriyet, April 1951.

[46] Republic Archieves of Turkish Prime Ministry, "Bank of Yap1-Kredi, Has Given Up to Open a Branch in Cyprus," (BCA) 30.10.0.0/ 138.989.11.

[47] Republic Archieves of Turkish Prime Ministry, "A Telegram From the Union of Turkish Cypriots to Prime minister Adnan Menderes," (BCA) 30.1.0.0/ 123.791.10.

[48] Commision for Cyprus Issue Has Established by the New Turkish MFA F.R. Zorlu, Ulus, July 1955.

[49] Republic Archieve of Turkish Prime Ministry, "Some of the Provocative News From the Geece Pres," (BCA), 30.1.0.0/129.839.5. (BCA), 30.1.0.0/129.839.5.

[50] Rumors Abaut the Killing of Turkish in Cyprus has Spreaded over Turkey, Cumhuriyet, August 1955.

[51] The Leader of the Main Opposition Party Ismet Inonu Cited his full support to the Ruling Party Leader A. Menderes, Ulus, August 26 , 1955.

[52] The Leader of C.M. Party O. Bolukbası Has explained his self Content for Menderes' Speech Abaut Cyprus Issue, Hurriyet, August 26, 1955.

[53] What is the Meaning of Silence of the Patriarchate? Yeni Sabah, July 03, 1955.

[54] Some News Abaut Patriach Athenagoras, Milliyet, August 27, 1955.

[55] A Demonstration for the Cyprus Issue has been Held Yesterday, Aksam, August 27, 1955.

[56] Z. Karaca, Fahri Coker Arsivi, 6/7 Eylul Olaylarl Fotograflar-Belgeler, İstanbul: Tarih Vakfı Yurt Yayınları, 2005.

[57] Security Precautions Increased Around the Patriarchate and in the Areas Which Mainly Inhabited by Greeks, Zafer, September 01, 1955.

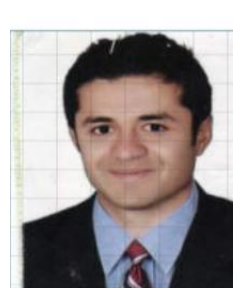

Resul Babaoglu is presently furthering his studies in $\mathrm{PhD}$ of the History of Turkish Republic at Ankara University. He obtained his master of education from Dicle Univesity. His bachelor degree is also in the field of history and the social sciences which he obtained from the University of Istanbul. He has published 6 articles and papers on subjects ranging from the early Turkish Republican era, Turkish Greek minority, Lausanne Peace Treaty and Historiography. His research interests include the modern Turkish history. He was awarded by Inonu Foundation for the paper writing competition which delicated to the 90 Anniversary of Lausanne Peace Treaty. 